\title{
Multimorbidity of Elderly Persons in Urban and Rural Areas of The Nizhny Novgorod Region
}

\author{
VI Starodubov' ${ }^{1}$ AN Edeleva', TP Sabgayda ${ }^{1 *}$
}

'Federal Research Institute for Health Organization and Informatics of Ministry of Health of Russian Federation, 11 Dobrolyubova Str., Moscow, 127254 , Russia

Article Info

\section{Article Notes}

Received: June 23, 2018

Accepted: July 25, 2018

\section{${ }^{\star}$ Correspondence:}

Dr. TP Sabgayda, Federal Research Institute for Health Organization and Informatics of Ministry of Health of Russian Federation, 11 Dobrolyubova Str., Moscow, 127254, Russia; Email: tsabgaida@mail.ru

C 2018 Sabgayda TP. This article is distributed under the terms of the Creative Commons Attribution 4.0 International License.

\section{Keywords:}

Multimorbidity

Prevalence of chronic diseases

Self-esteem of a health state

Persons of advanced age

Persons of senile age

Structure of morbidity

Original Article Citation: Starodubov VI, Edeleva AN Sabgayda TP. Multimorbidity of Elderly Individuals in Urban and Rural Areas of the Nizhny Novgorod Region. Adv Gerontol. 2018; 31(1):25-31

\section{ABSTRACT}

The article compares the prevalence of pathological changes in different organs and systems among city and rural residents of the next ages: elderly (60-74 years for men and 55-74 years for women), senile (75-84 years) and advanced ( 85 years and older) ages. The results of the continuous survey of all persons of the retirement age of one urban (7809 people) and two rural areas (14749) of the Nizhny Novgorod region were analyzed. The region is comparatively homogeneous in terms of the national composition of the population.

In the city, the number of chronic pathologies of different organs and systems per one person of elderly age are: 2.83 for man and 2.76 for woman of elderly ages, 3.06 and 3.07 respectively for senile ages, 2.71 and 2.75 of advanced ages. In rural areas, the analyzed indicators for men and women are respectively 1.64 and 1.58 for elderly ages, 1.84 and 1.78 for senile ages, 1.86 and 1.84 for advanced ages.

Demonstrating the difference in the phenotypic manifestations of the genes of predisposition to chronic diseases in old age between the city and village, the results make it possible to produce the following assumptions. First, better access to medical care does not guarantee the better health status of the elderly, while it contributes to an increase in the life expectancy of men. Second, in spite of better access to health care, urban lifestyle contributes to the accumulation of chronic diseases in population of a region. Third, if chronic pathology of three different classes of diseases presented, then the probability of a long life is fundamentally determined by the access to health care. Fourth, the probability of longevity is significantly reduced in result of illness by neoplasms, cardiovascular, respiratory, endocrine or genitourinary diseases in ages of working or beginning of retirement period.

In the Russian Federation, morbidity statistics for elderly people are formed for general group of pensioners (males 60 years old and older, females 55 years old and older) in case of their coming to physicians. There is high proportion of ill-defined causes in the mortality structure for elderly people. It means that health status of some persons remains uncertain. At the same time, in order to implement programs aimed to preserve the health of elderly, it is necessary to have more data on their health status. Development of chronic diseases in old age is genetically conditioned. Since urban and rural living conditions are different (including access to medical care), it is possible to expect a different phenotypic manifestation of the weak link genes among elderly residents of city and village.

The article compares the prevalence of pathological changes in different organs and systems among city and rural residents of the next ages: elderly (60-74 years for men and 55-74 years for women), 
senile (75-84 years) and long-lived (advanced, 85 years and older) ages. The results of the continuous survey of all persons of the retirement age of one urban (7809 people) and two rural areas (14749) of the Nizhny Novgorod region were analyzed (Table 1). Diseases and health status were detected in process of clinical examination and interview using active identification of all persons of retirement age in population that attached to the medical organization. A comparison of the incidence of diseases in different sexage groups of the population was carried out using the chisquare test.

The region is comparatively homogeneous in terms of the national composition of the population.

Proportions of elderly men among all pensioners in urban and rural areas are close, while proportion of elderly rural women is more than urban one $(\mathrm{p}<0.0001)$.

The greatest ages were observed in city for men $(114 \mathrm{vs}$ 99 years old in rural areas) and in countryside for women (106 vs 116).

For analyzed population, the registered incidence is

Table 1: Number of persons of retirement age in urban and rural areas of the Nizhny Novgorod region

\begin{tabular}{|c|c|c|c|c|}
\hline \multirow{2}{*}{ Age group } & \multicolumn{2}{|c|}{ City } & \multicolumn{2}{|c|}{ Rural areas } \\
\hline & men & women & men & women \\
\hline $\begin{array}{l}\text { Considered elderly } \\
\text { (60-74 years for men and } \\
55-74 \text { years for women) }\end{array}$ & 1664 & 3810 & 3662 & 5135 \\
\hline Senile (75-84 years) & 500 & 1236 & 1110 & 3337 \\
\hline $\begin{array}{l}\text { Long-lived } \\
\text { ( } 85 \text { years and older) }\end{array}$ & 147 & 452 & 260 & 1245 \\
\hline Total & 2311 & 5498 & 5032 & 9717 \\
\hline
\end{tabular}

Table 2: Standardized mortality and life expectancy at birth (LE) of the urban and rural population in the Nizhny Novgorod region and the Russian Federation and their growth for the period $2003-2016$ (European standard)

\begin{tabular}{|l|r|r|r|r|r|}
\hline \multirow{2}{*}{ Indicators } & \multicolumn{2}{|c|}{$\begin{array}{c}\text { Nizhny Novgorod } \\
\text { region }\end{array}$} & \multicolumn{2}{c|}{ Russian Federation } \\
\cline { 2 - 5 } & men & women & \multicolumn{1}{c|}{ men } & women \\
\hline Death rate in 2016 & 1579.2 & 1104.1 & 1356.1 & 1025.4 \\
\hline Growth rate (\%) & -34.6 & -29.7 & -35.7 & -31.2 \\
\hline LE0 in 2016 & 64.7 & 76.8 & 66.4 & 77.1 \\
\hline Growth (years) & 7.6 & 5.3 & 7.9 & 5.3 \\
\hline LE60 in 2016 & 14.9 & 21.2 & 16.3 & 21.9 \\
\hline Growth (years) & 3.1 & 3.1 & 3.3 & 3.3 \\
\hline & Rural areas & & & \\
\hline Death rate in 2016 & 1526.2 & 1109.9 & 1449.8 & 1086.7 \\
\hline Growth rate (\%) & -39.3 & -30.5 & -35.8 & -30.7 \\
\hline LE0 in 2016 & 64.7 & 75.8 & 65.4 & 76.2 \\
\hline Growth (years) & 8.8 & 5.8 & 7.9 & 5.2 \\
\hline LE60 in 2016 & 15.4 & 21.4 & 15.9 & 21.4 \\
\hline Growth (years) & 3.5 & 3.0 & 3.3 & 3.1 \\
\hline
\end{tabular}

slightly less, than for country, while death rate exceeds the average Russian mortality (1984.1 vs 2003.7 per 1000 people).

During the period 2003 - 2016, in compare with death rates for the country, regional mortality decreased to a smaller extent for urban population and to a greater extent for rural population (Table 2). So, life expectancy at birth for rural population has increased in more extent in the region than in country.

In compare with the country indexes, in analyzed region Life expectancy at 60 years old is less for urban residents and close for rural residents, and Life expectancy at birth is less for each area.

\section{Results}

Among urban residents, the proportions of those, who did not come to physicians during more than three years, are $12.8 \%$ for men and $11.6 \%$ for women while among rural people they are $50.6 \%$ and $45.5 \%(\mathrm{p}<0.0001)$.

Among all elderly, the proportion of urban residents, who cannot service themselves, is twice as large as the index for countryside (Table 3). For long-lived people these proportions are much larger, especially for men. The difference is statistically significant for long-lived men and women $(\mathrm{p}<0.0001)$. That means than rural residents remain active in self-service longer than townspeople.

During a survey of persons of retirement age it was determined that only a small part of the population has no chronic illnesses (Table 4).

We calculated the number of chronic diseases per person. In the city, the number of chronic pathologies of different organs and systems per one person of elderly age are: 2.83 for man and 2.76 for woman of elderly ages, 3.06 and 3.07 respectively for senile ages, 2.71 and 2.75 of advanced ages. In rural areas, the analyzed indicators for men and women are respectively 1.64 and 1.58 for elderly ages, 1.84 and 1.78 for senile ages, 1.86 and 1.84 for advanced ages.

Table 3: Proportions of elderly people who cannot service themselves (\%)

\begin{tabular}{|l|c|c|c|c|}
\hline \multirow{2}{*}{ Age group } & \multicolumn{2}{|c|}{ City } & \multicolumn{2}{c|}{ Rural areas } \\
\cline { 2 - 5 } & men & women & men & women \\
\hline Total & 11.1 & 11.6 & 4.7 & 6.2 \\
\hline $\begin{array}{l}\text { Long-lived } \\
\text { (85 years and older) }\end{array}$ & 42.2 & 37.6 & 10.4 & 11.5 \\
\hline
\end{tabular}

Table 4: Proportion of elderly people who did not have any diseases and comparison error

\begin{tabular}{|l|c|c|c|}
\hline & City & Rural areas & \multicolumn{1}{c|}{$\boldsymbol{P}$} \\
\hline Men & $0.74 \%$ & $0.26 \%$ & 0.003 \\
\hline Women & $1.05 \%$ & $0.31 \%$ & $<0.001$ \\
\hline
\end{tabular}


As we see for senile age group, for urban residents the number of chronic diseases is at one and a half times more than for rural population. In rural areas, there is an increase in the number of chronic diseases with age, and we don't see anything like this for city population. For urban residents of senile age with about three chronic diseases per person, the probability to live long are less than for people of this age with two chronic diseases.

Urban citizens, who cannot service themselves, have fewer illnesses per person than elderly people in total (Table 5). Among villagers, there is an opposite situation.

Table 5: Average number of chronic diseases per pensioner in the city and rural areas

\begin{tabular}{|l|c|c|c|c|}
\hline \multirow{2}{*}{} & \multicolumn{2}{|c|}{ City } & \multicolumn{2}{c|}{ Rural areas } \\
\cline { 2 - 5 } & men & women & men & women \\
\hline Total & 2.89 & 2.85 & 1.70 & 1.69 \\
\hline $\begin{array}{l}\text { People who cannot } \\
\text { service themselves }\end{array}$ & 2.54 & 2.68 & 1.84 & 1.87 \\
\hline
\end{tabular}

Using received data, we calculated the prevalence of chronic diseases among observed population. Its compare in three age groups of pensioners showed that neoplasms, endocrine, musculoskeletal and respiratory diseases among urban long-lived residents are less common than among senile age group (Table 6A). Note, among urban residents aged 85 and over, the prevalence of circulatory and nerve diseases is paradoxically less than among younger pensioners.

Among rural long-lived residents, as well as among the townspeople of this age, there are fewer neoplasms and endocrine diseases (Table 6B). Respiratory and musculoskeletal diseases are less common among rural long-lived males only. Also, long-lived males and females are less likely to have blood and genitourinary diseases. Prevalence of nerve and circulatory diseases among rural long-livers is greater than among younger pensioners, that is consistent with biological laws of these diseases development.

Table 6A: Prevalence of chronic diseases of different classes (per 1000 surveyed) among persons of considered elderly $(<75)$, senile $(75-84)$ and long-lived (85+) ages in Nizhny Novgorod city

\begin{tabular}{|c|c|c|c|c|c|c|}
\hline \multirow{2}{*}{ Classes of diseases } & \multicolumn{3}{|c|}{ Males } & \multicolumn{3}{|c|}{ Females } \\
\hline & $<75$ & $75-84$ & $>85$ & $<75$ & $75-84$ & $>85$ \\
\hline Infectious and parasitic diseases & 3.6 & 2.0 & 13.6 & 5.2 & 4.9 & 2.2 \\
\hline Neoplasms & 10.8 & 30.0 & 20.4 & 10.8 & 30.7 & 17.7 \\
\hline Blood diseases & 4.8 & 6.0 & 0.0 & 5.0 & 4.9 & 17.7 \\
\hline Endocrine diseases & 145.7 & 164.0 & 122.4 & 162.1 & 243.5 & 221.2 \\
\hline Mental disorders & 2.4 & 2.0 & 6.8 & 1.0 & 3.2 & 2.2 \\
\hline Nerve diseases & 21.7 & 10.0 & 6.8 & 27.0 & 12.9 & 2.2 \\
\hline Eye diseases & 125.2 & 92.0 & 183.7 & 113.9 & 119.7 & 161.5 \\
\hline Ear diseases & 15.1 & 56.0 & 6.8 & 10.2 & 10.5 & 13.3 \\
\hline Circulatory diseases & 1973.5 & 1960.0 & 1680.3 & 1982.7 & 2201.5 & 1911.5 \\
\hline Respiratory diseases & 22.9 & 84.0 & 54.4 & 19.9 & 68.0 & 48.7 \\
\hline Digestive diseases & 161.3 & 150.0 & 190.5 & 187.0 & 136.7 & 168.1 \\
\hline Musculoskeletal diseases & 427.5 & 240.0 & 217.7 & 231.1 & 216.8 & 154.9 \\
\hline Genitourinary diseases & 112.6 & 264.0 & 204.1 & 8.4 & 12.1 & 28.8 \\
\hline
\end{tabular}

Table 6B: Prevalence of chronic diseases of different classes (per 1000 surveyed) among persons of considered elderly (<75), senile (75-84) and long-lived ( $85+)$ ages in rural areas

\begin{tabular}{|c|c|c|c|c|c|c|}
\hline \multirow{2}{*}{ Classes of diseases } & \multicolumn{3}{|c|}{ Males } & \multicolumn{3}{|c|}{ Females } \\
\hline & $<75$ & $75-84$ & $>85$ & $<75$ & $75-84$ & $>85$ \\
\hline Infectious and parasitic diseases & 0.0 & 0.0 & 0.0 & 0.0 & 0.0 & 0.0 \\
\hline Neoplasms & 30.3 & 36.0 & 30.8 & 32.5 & 44.1 & 28.9 \\
\hline Blood diseases & 3.5 & 0.9 & 0.0 & 2.7 & 1.8 & 0.8 \\
\hline Endocrine diseases & 74.0 & 86.5 & 30.8 & 80.0 & 99.5 & 87.6 \\
\hline Mental disorders & 0.5 & 0.0 & 0.0 & 0.0 & 0.3 & 1.6 \\
\hline Nerve diseases & 4.9 & 6.3 & 30.8 & 4.1 & 10.8 & 31.3 \\
\hline Eye diseases & 2.2 & 4.5 & 3.8 & 1.6 & 7.5 & 5.6 \\
\hline Ear diseases & 0.3 & 1.8 & 0.0 & 0.0 & 1.2 & 4.0 \\
\hline Circulatory diseases & 1209.4 & 1316.2 & 1376.9 & 1192.2 & 1329.0 & 1343.8 \\
\hline Respiratory diseases & 40.4 & 42.3 & 34.6 & 22.6 & 25.2 & 34.5 \\
\hline Digestive diseases & 132.4 & 173.0 & 203.8 & 127.0 & 146.5 & 163.9 \\
\hline Musculoskeletal diseases & 118.8 & 136.9 & 130.8 & 105.6 & 101.3 & 131.7 \\
\hline Genitourinary diseases & 23.2 & 32.4 & 15.4 & 11.3 & 14.7 & 8.8 \\
\hline
\end{tabular}




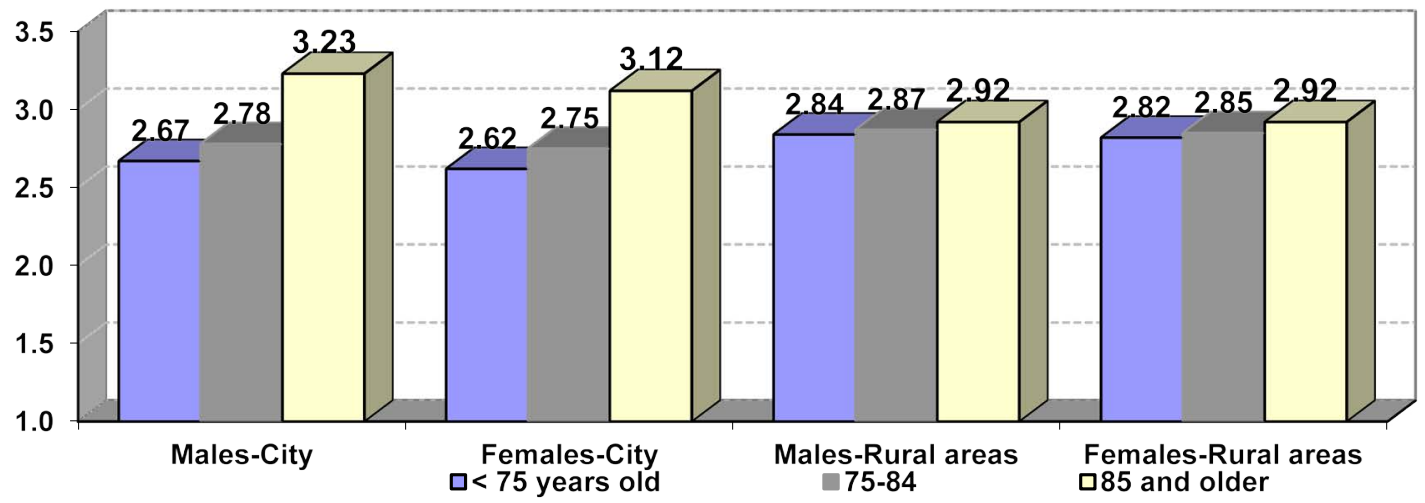

Figure 1. Average self-reported health status during last year by residents of cities and villages for different age groups (evaluation on a scale of 1 excellent, 2 good, 3 satisfactory, 4 bad)

In compare to urban residents, among rural residents, the prevalence of neoplasms is greater, and the prevalence of blood, endocrine, nerve, circulatory, respiratory, musculoskeletal and genitourinary diseases is less.

However, the ratio of urban and rural death rates is opposite for almost all these disease classes. Despite the large prevalence of neoplasms among rural residents, their mortality is less than in city (Table 6). With a greater prevalence among urban residents of nerve diseases, mortality from them is higher among rural residents. The same is for male mortality from circulatory, respiratory and musculoskeletal diseases. Death rates for blood and genitourinary diseases in city and villages are close.

Table 6: Death rates of urban and rural population of retirement age in the Nizhny Novgorod region, 2016 (European standard, per 100,000 population)

\begin{tabular}{|l|c|c|c|c|}
\hline \multirow{2}{*}{ Classes of diseases } & \multicolumn{2}{|c|}{ City } & \multicolumn{2}{c|}{ Rural areas } \\
\cline { 2 - 5 } & Males & Females & Males & Females \\
\hline Infectious and parasitic diseases & 16.3 & 4.4 & 6.2 & 1.2 \\
\hline Neoplasms & 1105.1 & 408.2 & 808.8 & 238.2 \\
\hline Blood diseases & 253.0 & 194.2 & 231.0 & 195.3 \\
\hline Endocrine diseases & 4.7 & 3.2 & 3.1 & 1.3 \\
\hline Mental disorders & 16.5 & 5.9 & 31.8 & 30.3 \\
\hline Nerve diseases & 936.4 & 650.0 & 1182.9 & 759.6 \\
\hline Circulatory diseases & 3182.4 & 1708.2 & 2772.1 & 1429.4 \\
\hline Respiratory diseases & 248.4 & 49.4 & 279.3 & 44.3 \\
\hline Digestive diseases & 276.8 & 130.6 & 217.4 & 119.0 \\
\hline Musculoskeletal diseases & 1.9 & 4.1 & 3.2 & 2.4 \\
\hline Genitourinary diseases & 53.5 & 27.7 & 52.3 & 31.3 \\
\hline Total & 6683.6 & 3651.5 & 6284.7 & 3549.8 \\
\hline
\end{tabular}

So, the structure of death causes does not adequately reflect the prevalence of chronic diseases and cannot serve as a basis for studying the population's need for specialized medical care in the field of gerontology.

We calculated average rank for self-reported health status during last year by residents of cities and villages for analyzed age groups using a scale of: 1 is excellent, 2 are good, 3 is satisfactory, 4 is bad.
For urban pensioners under the age of 75 this rank is more optimistic than for rural ones. However, urban longlivers have rated their health less optimistically than rural ones (Fig. 1).

It is possible that due to poor access to medical help, rural residents by the beginning of retirement age have learned to perceive malaises as a constant background of their life.

\section{Conclusion}

Demonstrating the difference in the phenotypic manifestations of the genes of predisposition to chronic diseases in old age between the city and village, the results make it possible to produce the following assumptions. First, better access to medical care does not guarantee the better health status of the elderly, while it contributes to an increase in the life expectancy of men. Second, in spite of better access to health care, urban lifestyle contributes to the accumulation of chronic diseases in population of a region. Third, if chronic pathology of three different classes of diseases presented, then the probability of a long life is fundamentally determined by the access to health care. Fourth, the probability of longevity is significantly reduced in result of illness by neoplasms, respiratory, endocrine or genitourinary diseases in combine with cardiovascular or nerve diseases.

\section{References}

1. Sanyika C, Corr P, Royston D, et al. Pulmonary angiography and embolization for severe hemoptysis due to cavitary pulmonary tuberculosis. Cardiovasc Intervent Radiol. 1999; 22(6): 457-60.

2. Auerbach 0. Pathology and pathogenesis of pulmonary arterial aneurysm in tuberculous cavities. Am Rev Tuberc. 1939; 39: 99- 115.

3. Plessinger VA, Jolly PN. Rasmussen's aneurysms and fatal hemorrhage in pulmonary tuberculosis. Am Rev Respir Dis. 1949; 60: 589- 603.

4. Rémy J, Smith M, Lemaitre L, et al. Treatment of massive hemoptysis by occlusion of a Rasmussen aneurysm. Am J Roentgenol. 1980; 135: 605- 606.

5. Patankar T, Prasad S, Deshmukh H. Fatal hemoptysis caused by ruptured giant Rasmussen's aneurysm. Am J Roentgenol. 2000; 174: 262- 263. 
6. Durak D, Eren B, Turkmen N, et al. Pulmonary artery aneurysm rupture Bratisl Lek Listy. 2008; 109: 582-583.

7. Smalcelj A, Brida V, Samarzija M, et al. Giant, dissecting, highpressure pulmonary artery aneurysm: case report of a 1-year natural course Tex Heart Inst J. 2005; 32: 589-594.

8. Yaméogo NV, Ndiaye MB, Diao M, et al. Dilatation anévrismale de l'artère pulmonaire et de ses branches sur sténose mitrale à propos d'un cas Ann Cardiol Angeiol. 2011; 10.1016/j.ancard.2010.12.020

9. Shankarappa RK, Moorthy N, Chandrasekaran N, et al. Giant pulmonary artery aneurysm secondary to primary pulmonary hypertension Tex Heart Inst J. 2010; 37: 244-245.

10. Ibn Elhadj Z, Keskes H, Kammoun I, et al. Anévrisme post-sténotique du tronc de l'artère pulmonaire chez un sujet de 70ans $J$ Mal Vasc. 2011; 36: 399-400.

11. Auerbach 0. Pathology and pathogenesis of pulmonary arterial aneurysm in tuberculous cavities. Am Rev Tuberc. 1939; 39: 99-115.

12. Plessinger VA, Jolly PN. Rasmussen's aneurysm and fatal hemorrhage in pulmonary tuberculosis. Am Rev Tuberc. 1949; 60: 589-603. 